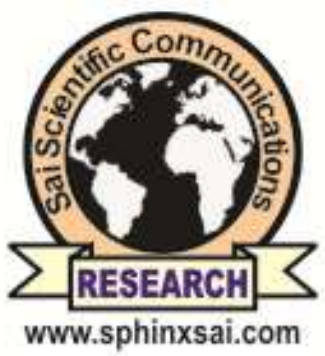

International Journal of PharmTech Research CODEN (USA): IJPRIF, ISSN: 0974-4304, ISSN(Online): 2455-9563

Vol.12, No.04, pp 01-06,

2019

\title{
The Characteristics of Patients With Giant Cell Tumors in General Hospital of Haji Adam Malik Medan In 2013-2018
}

\author{
Agus Salim ${ }^{1 \star}$, Nazar Moesbar ${ }^{2}$, Andriandi $^{3}$ \\ ${ }^{1}$ Resident of Orthopaedic \& Traumatology, Faculty of Medicine University of Sumatera \\ Utara/ Haji Adam Malik General Hospital-Medan, Indonesia \\ ${ }^{2}$ Professor and Consultant of Orthopaedic and Traumatology, Musculoskeletal \\ Oncology Division, Faculty of Medicine University of Sumatera Utara/ Haji Adam Malik \\ General Hospital-Medan, Indonesia \\ ${ }^{3}$ Consultant of Orthopaedic and Traumatology, Musculoskeletal Oncology Division, \\ Faculty of Medicine University of Sumatera Utara/ Haji Adam Malik General Hospital- \\ Medan, Indonesia
}

\begin{abstract}
Objective-Giant Cell Tumors (GCT) in bone is a rare musculoskeletal tumor. The purpose of this study was to study the characteristics of patients with Giant Cell Tumors in RSUP. Haji Adam Malik for 20132018. Materials and Methods-The type of research conducted is a retrospective descriptive research method. This research was conducted in RSUP. Adam Malik Haji Medan based on medical records of patients with Giant Cell Tumors during the period of January 2013 - December 2018. The collected medical and demographic data is tabulated and presented in the form of a frequency distribution chart or table and analyzed in full. Data analysis used in this study uses total sampling which is presented in the form of tables or diagrams.Results-During the period of the study taken from the medical record data of Medan Haji Adam Malik Hospital, 37 patients with Giant Cell Tumors were treated. Distribution of the number of sample subjects with diagnoses of giant cell tumors of male sex as many as 19 patients $(51.3 \%)$ while female sex numbered 18 patients $(48.6 \%)$. Based on the location of giant cell tumors obtained by distal radius of 3 patients $(8.1 \%)$, femur as many as 9 patients (24.3\%), fibula as many as 2 patients (5.4\%), proximal tibia as many as 14 patients (37, $9) \%$ ), then in categories other than long bones (digiti) as many as 5 patients (13.5\%), patella as many as 2 patients $(5.4 \%)$, and pedis as many as 2 patients $(5.4 \%)$. Based on the actions taken, as many as 21 people (56.7\%) carried out extensive excision, curettage + bone cement as many as 11 people (29.7\%), amputation in 3 patients $(8.1 \%)$, ORIF + bone grafts by 2 people (5.5\%). In this study, of 37 patients with giant cell tumors with stage 1 no patients, stage 2 as many as 12 people (32.4\%), stage 3 as many as 25 people (67.5\%). ConclusionPatients with tumor giant cells were found at productive age, there was not much difference in sex, the most campanacci stage was in stage 3 , the most common sites were proximal to the tibia, the most extensive measures were also available, and metastases were not available to other organs.
\end{abstract}

Keywords : Giant cell tumors, characteristic, metastasis, bone.

Agus Salim et al /International Journal of PharmTech Research, 2019,12(4): 01-06.

DOI: http://dx.doi.org/10.20902//JPTR.2019.120401 


\section{Introduction}

Giant Cell Tumor (GCT) in bone is a rare musculoskeletal tumor. ${ }^{1,2}$ GCT was first reported by Cooper in the 18th century, but it was not until 1940 that he defined the Giant Cell Tumor firmly from other tumors. ${ }^{1}$ GCTs include $4-5 \%$ of the incidence of primary bone tumors and $18.2 \%$ of the incidence of benign bone tumors. ${ }^{1,3}$ Approximately $60 \%$ of Giant Cell Tumors occur in long bones and almost all occur at the distal end of the bone, especially in the femur, tibia, humerus, and radius. ${ }^{2,4}$

These tumors are quite common in Southeast Asia, especially in China with an incidence of up to 20\%. ${ }^{5,6}$ Women suffer more from Giant Cell Tumors than men. The incidence of Giant Cell Tumors is the highest at the age of 20-45 years. About $85 \%$ of tumors occur in those older than 19 years with the highest incidence occurring in the third decade of life.

Giant Cell Tumors have microscopic images that resemble other bone tumors, which also have a picture of multinucleated osteoclast-like giant cells such as chondroblastoma, chondromyxoid fibroma, and chondrosarcoma. ${ }^{6}$ Diagnosis through examination of anatomic pathology still needs to be confirmed by clinical findings. available, but $50 \%$ of patients still experience local recurrence, even in some cases pulmonary metastasis can occur. ${ }^{7}$

Until now there has been no data in Indonesia, especially in Medan, the researchers were interested in conducting research to look for patient characteristics of Giant Cell Tumors and the characteristics of patients who had taken action.

\section{Method}

This type of research is a retrospective descriptive research method which is intended to describe patients with giant cell tumors based on facts that have occurred and recorded in medical records. This research was conducted in RSUP. Adam Malik Haji Medan based on medical records of patients with Giant Cell Tumors during the period of January 2013 - December 2018. The study was conducted after the ethics committee approved.

The inclusion criteria for this study were complete medical records of patients treated with a diagnosis of Giant Cell Tumors in RSUP. Haji Adam Malik Medan period January 2013 - December 2018. The inclusion criteria of this study are incomplete medical record data for patients with Giant Cell Tumour.

The data used are secondary data taken from the records in the medical record of Giant Cell Tumor patients in RSUP. Haji Adam Malik Medan period January 2013 - December 2018. Medical data and demographics collected are tabulated and presented in the form of a frequency distribution chart or table and analyzed descriptively. The data analysis used in this study is to use total sampling presented narratively in the form of tables or diagrams.

All statistical calculations are carried out using a computer-based statistical program. This study was approved by the Hospital Health Research Ethics Committee of the Faculty of Medicine, University of North Sumatra / Haji Adam Malik.

\section{Results}

This research was conducted in April 2019. The data collection was carried out in the Medical Record Installation of Haji Adam Malik Hospital in Giant Cell Tumors patients who came to treatment at the determined research sites, namely in the period January 2013 - December 2018. Data collection was carried out in stages with the initial stage is to select a sample of subjects who are included in the inclusion criteria and to collect the patient's raw data and to be sorted systematically. Medical record data of Haji Adam Malik Hospital in Medan found 37 patients with Giant Cell Tumors who were treated. 
Table 1. Gender and age Demographic Distribution of Subjects with giant cell tumour

\begin{tabular}{|l|l|}
\hline Variable & Total \\
\hline Female, $\mathrm{n}(\%)$ & $18(48,6 \%)$ \\
\hline Male, $\mathrm{n}(\%)$ & $19(51,3 \%)$ \\
\hline Youngest age & 22 years \\
\hline Oldest age & 74 year \\
\hline Mean & $38,84 \pm 9,937$ \\
\hline
\end{tabular}

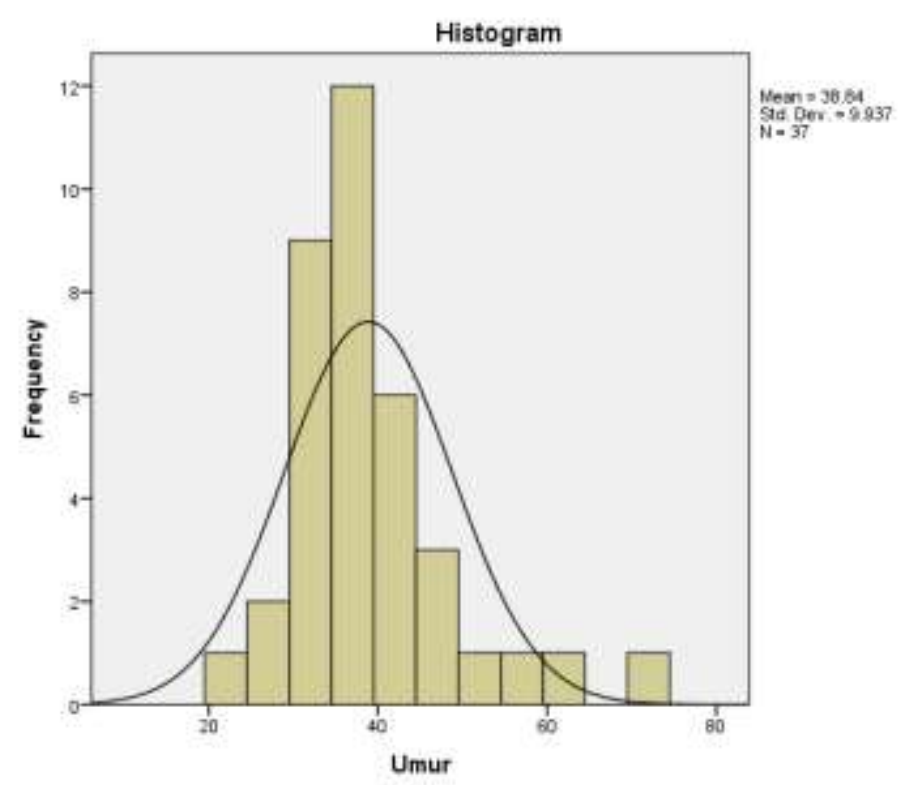

Figure 1. Distribution of Demographic Age Characteristics of Subjects diagnosed with Giant Cell Tumors

Table 1 shows that the distribution of the number of subjects with diagnoses Giant cell tumour is male sex as many as 19 patients (51.3\%) while female sex is as many as 18 patients (48.6\%) which means that giant cell tumor patients more common in patients with male sex.

In the results of this study, the distribution of patients with giant cell tumors based on the location of giant cell tumors in the category of long bones: distal radius as many as 3 patients $(8.1 \%)$, femur as many as 9 patients $(24.3 \%)$, fibula as many as 2 patients $(5,4 \%)$, proximaltibia as many as 14 patients $(37.9 \%)$, then in categories other than long bones (digiti) as many as 5 patients (13.5\%), patella as many as 2 patients $(5.4 \%)$, and pedis as many as 2 patients $(5.4 \%)$.

Table 2. Distribution of research subjects based on the location of giant cell tumors

\begin{tabular}{|l|l|l|l|}
\hline No & Giant Cell Tumor Location & N & \% \\
\hline 1 & Digiti & 5 & 13,5 \\
\hline 2 & Distal Radius & 3 & 8,1 \\
\hline 3 & Femur & 9 & 24,3 \\
\hline 4 & Fibula & 2 & 5.4 \\
\hline 5 & Patella & 2 & 5.4 \\
\hline 6 & Pedis & 2 & 5.4 \\
\hline 7 & Proksimal Tibia & 14 & 37,9 \\
\hline & Total & 37 & 100 \\
\hline
\end{tabular}


In the results of this study, of 37 giant cell tumor patients who performed wide excision as many as 21 people $(56.7 \%)$, curettage + bone cement as many as 11 people $(29.7 \%)$, amputation as many as 3 patients $(8.1 \%)$, ORIF + bone graft as many as 2 people $(5.5 \%)$, which means that tumor giant cell patients have more wide-action measures as many as 21 patients $(56.7 \%)$.

Table 3. Distribution of research subjects based on actions

\begin{tabular}{|l|l|l|l|}
\hline No & Action & N & \% \\
\hline 1 & Wide excision & 21 & 56,7 \\
\hline 2 & Kuretase + bone cement & 11 & 29,7 \\
\hline 3 & Amputastion & 3 & 8,1 \\
\hline 4 & ORIF + bone graft & 2 & 5,5 \\
\hline & Total & 37 & 100 \\
\hline
\end{tabular}

In the results of this study, of the 37 giant cell tumor patients with stage 1 there were no patients, stage 2 was 12 people (32.4\%), stage 3 were 25 people (67.5\%).

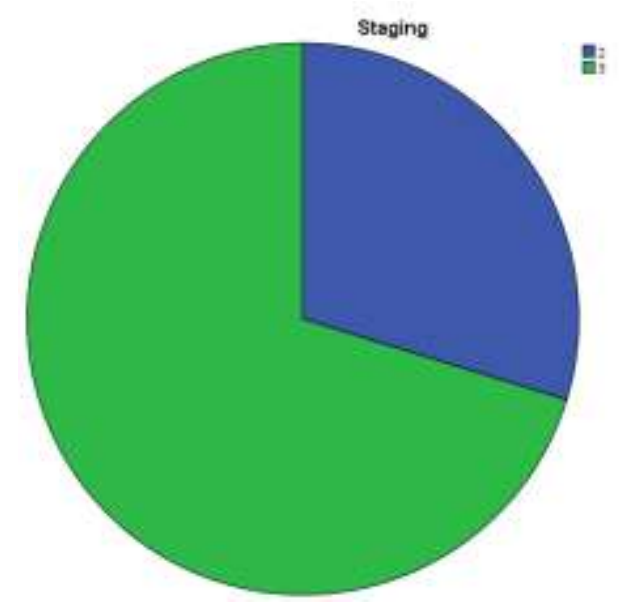

Table 4. Distribution of research subjects based on campanacci staging

\begin{tabular}{|l|l|l|l|}
\hline No & Campanaci Staging & N & \% \\
\hline 1 & Stage 1 & 0 & 0 \\
\hline 2 & Stage 2 & 12 & 32,4 \\
\hline 3 & Stage 3 & 25 & 67,5 \\
\hline & Total & 37 & 100 \\
\hline
\end{tabular}

In this study, none of the metastatic patients with giant cell tumors, while those who did not metastasize were as many as 37 patients (100\%), which means that patients with giant cell tumors did not metastasize.

Table 5. Distribution of research subjects based on metastasis

\begin{tabular}{|l|l|l|l|}
\hline No & Status & N & \% \\
\hline 1 & No Metastasis & 37 & 100 \\
\hline 2 & Metastasis & 0 & 0 \\
\hline & Total & 37 & 100 \\
\hline
\end{tabular}




\section{Discussion}

This study aims to determine the characteristics of patients with giant cell tumour at the Adam Malik Haji Hospital in Medan. In the discussion section, discussions will be conducted based on patient characteristics, namely the age of the patient, gender, religion, ethnicity, tumor location, actions taken and metastasis.

This study was conducted with a retrospective descriptive study method with a crossectional approach, which aims to determine the characteristics of patients diagnosed with Giant cell tumour and seek treatment at H. Adam Malik Hospital in Medan.

According to A. Liede et al., Patients diagnosed with Giant Cell Tumors generally at a young age (2040 years) with an average age of 38.84 years, this is in accordance with the research conducted, with a mean age of 34.4 years. Based on gender, it was found that there was not too much difference between the rate of giant cell tumour events related to sex, this was in accordance with what was revealed by A. Liede et al where there were no differences in sex incidence rates. Based on staging, the majority of this study was stage 3 and wide resection was carried out, this is consistent with the research conducted by Carsten et al. Based on the location of giant cell tumour, the most affected is in the tibia and in the distal part of the femur, this in accordance with the research conducted by Arie et al, Zanati et al where the most sites were tibia and femur. Based on the action, the most common action was wide excision + reconstruction of 25 patients $(65.7 \%)$, this is different from the African study conducted by Zanati et al where the most common surgical procedure was wide excision + reconstruction. Based on the recurrence rate at 6 months follow-up, there was no recurrence even though there was a difference with the research conducted by Kabul, et al. That the recurrence rate in the case of Giant cell tumour camp 2 and 3 reached $34.4 \%$. The majority of patients in the study did not have metastasis according to the study by Zanati et al. Where GCT was generally not metastatic.

\section{Conclusion}

Patients with giant cell tumors are often found in the productive age, there are not too many differences in sex, stage campanacci most at stage 3, the location most often found in the proximal tibia, the most wide excision action, and also no metastasis to other organs.

\section{References}

1. R G Forsyth, G De Boeck, S Bekaert, dkk. Telomere Biology in Giant Cell Tumour of Bone. in : J Pathol 2008; 214. h. 555-563.

2. Kamal A F, Aminata I W, Hutagalung E U. Giant Cell Tumor Jaringan Lunak. in : Maj Kedokt Indon, Volum: 57, Nomor: 11, Nopember 2007. h. 404-407

3. Silvers A R, Peter M S, Margaret B, dkk. The Role of Imaging in the Diagnosis of Giant Cell Tumor of the Skull Base. in : Tumor of Skull Base, August 1996. h . 1392-1395.

4. Lesley- Ann Goh. Giant Cell tumor imaging. May 25, 2011. Available from URL : http://emedicine.medscape.com

5. Forsyth RG, Hogendoorn PCW. Bone: Giant cell tumor. June 2003. Available from URL : http://atlasgeneticsoncology.org

6. American Academy of Orthopedics Surgeons. Giant Cell Tumor of Bone. June 2010. Available from URL : http//orthoinfo.org

7. $\quad$ Ekayuda I. Radiologi Diagnostik edisi kedua. Jakarta : Balai Penerbit FKUI; 2005. h. 76-81.

8. Folpe Andrew L,Inwards Carrie Y.Bone and Soft Tissue Pathology. $1^{\text {st }}$.ed. Goldblum John R,editor.china: Saunders Elsevier,2009. 401-7p.

9. Damron Timothy A.Oncology and Basic Science. $7^{\text {th }}$.ed. Tornetta,Paul,Thomas A,editor.New York: Lippincott Williams\&Wilkins; 2008 .159-64p.

10. Flethcer Christopher D.M. World Health Organization Classification of Tumors Pathology and Genetics of Tumors of Soft Tissue and Bone. Unni K. Krishnan,Mertens F,editor. Lyon: WHO; 2002. 310-13p.

11. Bullough Peter G. Orthopaedic Pathology. $5^{\text {th }}$. ed. Missouri: Mosby Elsevier,2010.466-74p 
12. Unni K. Krishnan. Dahlin's Bone Tumors United VRG. $6^{\text {th }}$.ed. Inwards Carrie Y.Philadelphia:Lippincot Williams\&Wilkins,2010.298p.

13. Wheeless' Textbook of Orthopaedics. Giant-cell tumor of bone. March 2011. Available from URL : http ://www.wheelessonline.com.

14. Salter Robert B. Textbook of Disorders and Injuries of the Muskuloskeletal System. $3^{\text {rd }}$.ed. Pennsylvania: Wiiliams \&Wilkins, 1999. 408 p.

15. Heck Robert K, Toy Patrick C. Campbell Operative Orthopaedics. $13^{\text {th }}$. ed. Philadelphia: Elsevier, 2017.923p.

16. Chakarun Corey F. Giant Cell Tumor of Bone: Review, Mimics, and New Developments in Treatment [Internet]. Rsna. 2013 [cited January 2013]. Available from: https://pubs.rsna.org/doi/pdf/10.1148/rg.331125089 